similar for W24-52 (0.62) and W0-24 (0.46) for Q4W; less radiographic progression occurred from W24-52 v W0-24 for Q8W (0.23 v 0.73) \& PBO X Q4W (0.25 v 1.00). In 731 GUS-treated pts, $4.2 \%$ had SAEs; $1.2 \%$ had serious infections; no pt died; and no pt had IBD, opportunistic infections or active TB, or anaphylactic or serum sickness-like reactions.

Conclusion: In biologic-naïve pts with active PsA, GUS elicited sustained improvements in joint \& skin symptoms; inhibition of radiographic progression \& improvements in physical function, quality of life \& composite indices through W52. GUS safety in PsA was similar at W24 $4^{1}$ \& W52 and consistent with GUS safety in psoriasis.

References:

[1] Mease P (A\#L13), Arthritis Rheumatol 2019;71(suppl 10)

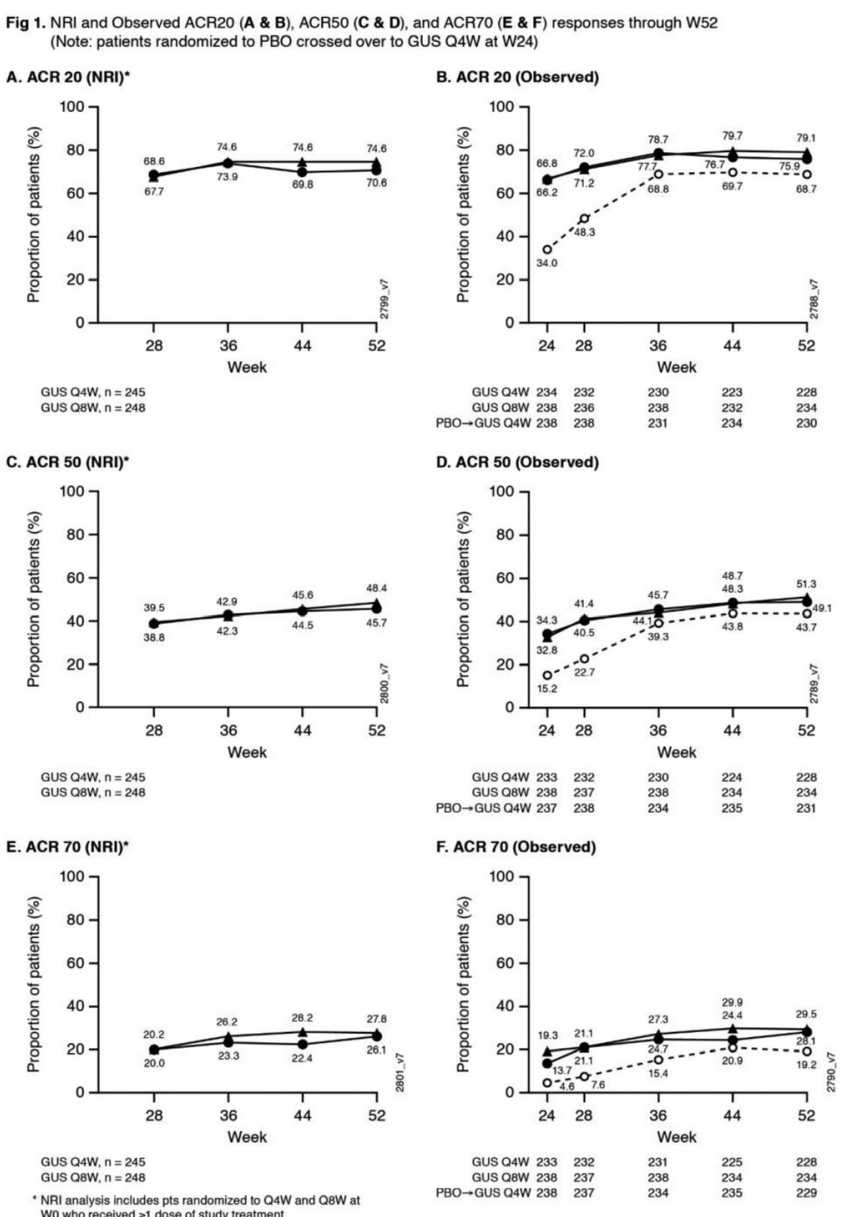

$\rightarrow$ GUS $100 \mathrm{mg}$ Q4W $\leftrightarrows$ GUS $100 \mathrm{mg}$ Q8W $\quad \cdots$-O.. PBO $\rightarrow$ GUS $100 \mathrm{mg}$ Q4W

\section{Acknowledgments: None}

Disclosure of Interests: lain Mclnnes Grant/research support from: Bristol-Myers Squibb, Celgene, Eli Lilly and Company, Janssen, and UCB, Consultant of: AbbVie, Bristol-Myers Squibb, Celgene, Eli Lilly and Company, Gilead, Janssen, Novartis, Pfizer, and UCB, Proton Rahman Grant/research support from: Janssen and Novartis, Consultant of: Abbott, AbbVie, Amgen, BMS, Celgene, Lilly, Janssen, Novartis, and Pfizer., Speakers bureau: Abbott, AbbVie, Amgen, BMS, Celgene, Lilly, Janssen, Novartis, Pfizer, Alice B Gottlieb Grant/research support from:: Research grants, consultation fees, or speaker honoraria for lectures from: Pfizer, AbbVie, BMS, Lilly, MSD, Novartis, Roche, Sanofi, Sandoz, Nordic, Celltrion and UCB., Consultant of:: Research grants, consultation fees, or speaker honoraria for lectures from: Pfizer, AbbVie, BMS, Lilly, MSD, Novartis, Roche, Sanofi, Sandoz, Nordic, Celltrion and UCB., Speakers bureau:: Research grants, consultation fees, or speaker honoraria for lectures from: Pfizer, AbbVie, BMS, Lilly, MSD, Novartis, Roche, Sanofi, Sandoz, Nordic, Celltrion and UCB., Elizabeth C Hsia Shareholder of: Johnson \& Johnson, Employee of: Janssen Research \& Development, LLC, Alexa Kollmeier Shareholder of: Johnson \& Johnson, Employee of: Janssen Research \& Development, LLC, Xie L Xu Shareholder of: Johnson \& Johnson, Employee of: Janssen Research \& Development, LLC, Ramanand A Subramanian Employee of: Janssen Research \& Development, LLC, Prasheen Agarwal Shareholder of: Johnson \& Johnson, Employee of: Janssen Research \& Development, LLC, Shihong Sheng Shareholder of: Johnson \& Johnson, Employee of: Janssen Research \& Development, LLC, Yusang
Jiang: None declared, Bei Zhou Shareholder of: Johnson \& Johnson, Employee of: Janssen Research \& Development, LLC, Désirée van der Heijde Consultant of: AbbVie, Amgen, Astellas, AstraZeneca, BMS, Boehringer Ingelheim Celgene, Cyxone, Daiichi, Eisai, Eli-Lilly, Galapagos, Gilead Sciences, Inc. Glaxo-Smith-Kline, Janssen, Merck, Novartis, Pfizer, Regeneron, Roche, Sanofi, Takeda, UCB Pharma; Director of Imaging Rheumatology BV, Philip J Mease Grant/research support from: Abbott, Amgen, Biogen Idec, BMS, Celgene Corporation, Eli Lilly, Novartis, Pfizer, Sun Pharmaceutical, UCB - grant/research support, Consultant of: Abbott, Amgen, Biogen Idec, BMS, Celgene Corporation, Eli Lilly, Novartis, Pfizer, Sun Pharmaceutical, UCB - consultant, Speakers bureau: Abbott, Amgen, Biogen Idec, BMS, Eli Lilly, Genentech, Janssen, Pfizer, UCB - speakers bureau

DOI: 10.1136/annrheumdis-2020-eular.852

\section{SAT0403 EFFICACY AND SAFETY OF 108 WEEKS' BIMEKIZUMAB TREATMENT IN PATIENTS WITH PSORIATIC ARTHRITIS: INTERIM RESULTS FROM A PHASE 2 OPEN-LABEL EXTENSION STUDY}

I. Mcinnes ${ }^{1}$, J. F. Merola ${ }^{2}$, P. J. Mease ${ }^{3}$, L. C. Coates ${ }^{4}$, P. Joshi ${ }^{5}$, J. Coarse ${ }^{6}$, B. Ink ${ }^{5}$, C. T. Ritchlin ${ }^{7}{ }^{1}$ University of Glasgow, Glasgow, United Kingdom; ${ }^{2}$ Harvard Medical School, Brigham and Women's Hospital, Boston, United States of America; ${ }^{3}$ Swedish Medical Center and University of Washington, Seattle, United States of America; ${ }^{4}$ University of Oxford, Oxford, United Kingdom; ${ }^{5}$ UCB Pharma, Slough, United Kingdom; ${ }^{6}$ UCB Pharma, Raleigh, United States of America; ${ }^{7}$ University of Rochester Medical Center, Rochester, United States of America

Background: Bimekizumab (BKZ), a monoclonal antibody that selectively neutralises IL-17A and IL-17F, has shown clinical improvements in skin and joint outcomes over 48 weeks (wks) in patients (pts) with active psoriatic arthritis (PsA). Objectives: To report 2-year interim results from a phase $2 b$ dose-ranging study (BE ACTIVE; NCT02969525) and open-label extension (OLE; NCT03347110) of BKZ in pts with PsA.

Methods: Design of the dose-ranging study is described elsewhere. ${ }^{1}$ Pts who completed 48 wks' BKZ treatment without meeting withdrawal criteria were eligible for OLE entry. All OLE pts received BKZ $160 \mathrm{mg}$ Q4W, irrespective of prior dosing regimen.

Data are presented from dose-ranging study baseline (BL) to OLE Wk 60 (Wk 108 total). Efficacy outcomes are reported for the full analysis set (FAS): pts who received $\geq 1$ dose BKZ (specifically those randomised to $160 \mathrm{mg}, 160 \mathrm{mg}$ with $320 \mathrm{mg}$ loading dose [LD], or $320 \mathrm{mg}$ at $\mathrm{BL}$ ), with BL efficacy measurements to allow subsequent determination of ACR50. Outcomes include ACR20/50/70, body surface area (BSA) $0 \%$, minimal disease activity (MDA), and enthesitis/ dactylitis resolution. Rates of treatment-emergent adverse events (TEAEs) are reported for the Safety Set (SS; pts who received $\geq 1$ dose BKZ in the dose-ranging study).

Results: BL mean (SD) tender/swollen joint counts were 21.7 (15.7) and 11.2 (8.4). $80(65.0 \%)$ pts had BSA $\geq 3 \%$ and dactylitis/enthesitis were present in $41(33.3 \%)$ and $68(55.3 \%)$ pts. Over 108 wks' BKZ treatment, improvements were observed in skin/joint outcomes: ACR50 (66.7\%), BSA 0\% (75.4\%), MDA $(65.6 \%)$, and resolution of dactylitis $(65.9 \%)$ and enthesitis $(77.9 \%)$ (Table). Serious TEAEs occurred in $9.3 \%$ pts (Table); no deaths or major adverse cardiac events were reported. Oral candidiasis occurred in $16(7.8 \%)$ pts (no serious cases)

Conclusion: BKZ leads to long-term efficacy for skin/joint manifestations of PsA, with $>50 \%$ pts achieving high thresholds of disease control (ACR50, BSA $0 \%$, MDA) after 108 wks' treatment. The safety profile reflects previous observations. References:

[1] Ritchlin CT. Ann Rheum Dis 2019;78:127-8.

Acknowledgments: This study was funded by UCB Pharma. Editorial services were provided by Costello Medical.

Disclosure of Interests: lain McInnes Grant/research support from: Bristol-Myers Squibb, Celgene, Eli Lilly and Company, Janssen, and UCB, Consultant of AbbVie, Bristol-Myers Squibb, Celgene, Eli Lilly and Company, Gilead, Janssen, Novartis, Pfizer, and UCB, Joseph F. Merola Consultant of: Merck, AbbVie, Dermavant, Eli Lilly, Novartis, Janssen, UCB Pharma, Celgene, Sanofi, Regeneron, Arena, Sun Pharma, Biogen, Pfizer, EMD Sorono, Avotres and LEO Pharma, Philip J Mease Grant/research support from: AbbVie, Amgen, Bristol-Myers Squibb, Janssen, Eli Lilly, Novartis, Pfizer, Sun Pharma, UCB Pharma, Consultant of: AbbVie, Amgen, Bristol-Myers Squibb, Celgene, Janssen, Eli Lilly, Galapagos, Gilead, Novartis, Pfizer, Sun Pharma, UCB Pharma, Speakers bureau: AbbVie, Amgen, Bristol-Myers Squibb, Celgene, Genentech, Janssen, Novartis, Pfizer, UCB Pharma, Laura C Coates: None declared, Paulatsya Joshi Employee of: UCB Pharma, Jason Coarse Employee of: UCB Pharma, Barbara Ink Shareholder of: GlaxoSmithKline and UCB Pharma, Employee of: UCB Pharma, Christopher T. Ritchlin Grant/research support from: UCB Pharma, AbbVie, Amgen, 
Table. Outcomes at OLE Wk 60 (Wk 108 total)

\begin{tabular}{|c|c|c|c|c|c|c|}
\hline & \multicolumn{2}{|c|}{$\mathrm{BKZ} 160 \mathrm{mg}$ [a] $(\mathrm{N}=82)$} & \multicolumn{2}{|c|}{ BKZ $320 \mathrm{mg}$ [a] $(\mathrm{N}=41)$} & \multicolumn{2}{|c|}{$\mathrm{BKZ}$ total $(\mathrm{N}=123)$} \\
\hline & OC & NRI & OC & NRI & OC & NRI \\
\hline \multicolumn{7}{|l|}{ Efficacy (FAS) n (\%) } \\
\hline ACR20 & $53 / 62(85.5)$ & $53(64.6)$ & 29/37 (78.4) & $29(70.7)$ & 82/99 (82.8) & $82(66.7)$ \\
\hline ACR50 & $41 / 62(66.1)$ & $41(50.0)$ & $25 / 37(67.6)$ & $25(61.0)$ & $66 / 99(66.7)$ & 66 (53.7) \\
\hline ACR70 & $34 / 62(54.8)$ & 34 (41.5) & $19 / 37(51.4)$ & 19 (46.3) & $53 / 99(53.5)$ & 53 (43.1) \\
\hline $\mathrm{BSA} 0 \%[\mathrm{~b}]$ & $35 / 42(83.3)$ & - & $14 / 23(60.9)$ & - & $49 / 65(75.4)$ & - \\
\hline MDA [c] & $43 / 61(70.5)$ & $43(52.4)$ & 20/35 (57.1) & $20(48.8)$ & $63 / 96(65.6)$ & $63(51.2)$ \\
\hline Dactylitis resolution & - & $16 / 27(59.3)$ & - & $11 / 14(78.6)$ & - & $27 / 41(65.9)$ \\
\hline Enthesitis resolution [c] & - & $34 / 45(75.6)$ & - & 19/23 (82.6) & - & $53 / 68$ (77.9) \\
\hline $\begin{array}{l}\text { Safety (SS) } \\
\text { n (\%) [EAER] }\end{array}$ & \multicolumn{2}{|c|}{$\begin{array}{l}\text { BKZ } 160 \mathrm{mg} \text { [d] } \\
\quad(\mathrm{N}=198)\end{array}$} & \multicolumn{2}{|r|}{$\begin{array}{l}\text { BKZ } 320 \mathrm{mg}[\mathrm{d}] \\
\quad(\mathrm{N}=80)\end{array}$} & \multicolumn{2}{|c|}{$\begin{array}{l}\text { BKZ total [d, e] } \\
\quad(\mathrm{N}=204)\end{array}$} \\
\hline Any TEAE & \multirow{2}{*}{\multicolumn{2}{|c|}{$\begin{array}{c}163(82.3)[160.9] \\
17(8.6)\end{array}$}} & \multirow{2}{*}{\multicolumn{2}{|c|}{$\begin{array}{c}57(71.3)[299.8] \\
1(1.3)\end{array}$}} & \multicolumn{2}{|c|}{$179(87.7)[181.1]$} \\
\hline $\begin{array}{l}\text { Study discontinuation due } \\
\text { to TEAEs }\end{array}$ & & & & & & \\
\hline $\begin{array}{l}\text { Permanent withdrawal of } \\
\text { study drug due to TEAEs }\end{array}$ & \multicolumn{2}{|c|}{$16(8.1)$} & \multicolumn{2}{|r|}{$2(2.5)$} & \multicolumn{2}{|c|}{$18(8.8)$} \\
\hline Drug-related TEAEs & \multicolumn{2}{|c|}{72 (36.4) } & & \multicolumn{2}{|c|}{$92(45.1)$} \\
\hline Serious TEAEs & \multicolumn{2}{|c|}{19 (9.6) [4.8] } & \multicolumn{2}{|r|}{$\begin{array}{c}29(36.3) \\
0\end{array}$} & \multicolumn{2}{|c|}{$19(9.3)[4.1]$} \\
\hline
\end{tabular}

[a] BKZ $160 \mathrm{mg}$ pts received this dose continuously to Wk 108 (includes those originally assigned to $160 \mathrm{mg}$ with LD); BKZ $320 \mathrm{mg}$ pts were dose-reduced to $160 \mathrm{mg}$ at OLE entry; [b] Pts with BSA $\geq 3 \%$ at BL; [c] Data from OLE Wk 72 (Wk 120 total); [d] Dose received at TEAE onset (pts may be counted in multiple columns); [e] Includes pt time on BKZ 16 mg. EAER: exposure-adjusted event rate; NRI: non-responder imputation; OC: observed case.

Consultant of: UCB Pharma, Amgen, AbbVie, Lilly, Pfizer, Novartis, Gilead, Janssen

DOI: 10.1136/annrheumdis-2020-eular.1850

\section{SAT0404 INCIDENCE OF PSORIATIC ARTHRITIS FROM 2000-2017: A POPULATION-BASED STUDY}

P. Karmacharya ${ }^{1}$, C. S. Crowson ${ }^{2}$, D. Bekele ${ }^{1}$, S. Achenbach ${ }^{2}$, J. M. Davis III $^{1}$, A. Ogdie ${ }^{3}$, A. Duarte-Garcia ${ }^{1}$, H. Maradit-Kremers ${ }^{2}$, M. Tollefson ${ }^{4}$, F. C. Ernste ${ }^{1}, \mathrm{~K}$. Wright ${ }^{1} .^{1}$ Mayo Clinic, Division of Rheumatology, Rochester, United States of America; ${ }^{2}$ Mayo Clinic, Department of Health Sciences Research, Rochester, United States of America; ${ }^{3} \mathrm{Hospital}$ of the University of Pennsylvania, Division of Rheumatology, Philadelphia, United States of America; ${ }^{4}$ Mayo Clinic, Department of Dermatology, Rochester, United States of America

Background: Psoriatic arthritis (PsA) is a chronic inflammatory musculoskeletal disease with an estimated prevalence of $0.05 \%$ to $0.25 \%$ in the population and $6 \%$ to $41 \%$ in psoriasis patients. There is disparity in the reported incidence patterns in the general population in more recent years, with increasing incidence seen in Denmark, but relatively stable rates seen in Canada. However, no studies in the US have looked at the recent incidence patterns, and it would be important to see how newer therapies for psoriasis have impacted the incidence of PsA. Variability in the estimates of incidence and prevalence across different studies has been attributed to differences in case ascertainment and most studies have used ICD codes to identify PsA patients.

Objectives: To determine the annual incidence of PsA (2000-17) and compare it to incidence of PsA in previous years $(1970-1999)^{1}$ in the Olmsted County, Minnesota, USA population.

Methods: A retrospective, population-based cohort of PsA patients $\geq 18$ years of age from Olmsted County, MN meeting CIASsification of Psoriatic ARthritis (CASPAR) criteria for PsA (2000-17) was identified from the Rochester Epidemiology Project (REP). REP ensures virtually complete ascertainment and follow-up of all clinically diagnosed cases of PsA in a geographically-defined area. The date of fulfillment of CASPAR criteria was taken as the PsA incidence date. Age- and sex-specific incidence rates, adjusted to 2010 US white population, were reported. Our previously reported cohort from REP (19701999) ${ }^{1}$ also used the same CASPAR criteria, and trends from the current study were compared to the previous years.

Results: There were 170 incident cases of PsA, with a mean age of 46.7 $(S D=12.3)$ years and $47 \%$ females from $2000-17$. The overall age and sex adjusted annual incidence of PsA per 100,000 population was $8.8(95 \% \mathrm{Cl}$ 7.5-10.1), and higher in males $(9.7,95 \% \mathrm{Cl} 7.7-11.7)$ than females $(8.0,95 \%$ $\mathrm{Cl}$ 6.2-9.8). Overall incidence was highest in the age range 40-59 years (Table 1). The incidence rate was relatively stable in the recent years 20002017 compared to $1970-1999^{1}$ where a rise in incidence was observed (3.6 to 9.8 per 100,000 persons from $1970-79$ to $1990-99, p<0.001$ ) (Figure 1).
Table 1. Annual incidence rate, IR (per 100,000) of psoriatic arthritis by age and sex between 2000-17 in Olmsted County, MN.

\begin{tabular}{|c|c|c|c|c|c|c|}
\hline \multirow[b]{2}{*}{ Age Group, yrs } & \multicolumn{2}{|r|}{ Male } & \multicolumn{2}{|r|}{ Female } & \multicolumn{2}{|r|}{ Total } \\
\hline & $\mathrm{N}$ & IR & $\mathrm{N}$ & IR & $\mathrm{N}$ & Rate \\
\hline $18-29$ & 9 & 4.1 & 4 & 1.6 & 13 & 2.8 \\
\hline $30-39$ & 24 & 13.4 & 14 & 7.3 & 38 & 10.2 \\
\hline $40-49$ & 24 & 13.9 & 26 & 14.0 & 50 & 14.0 \\
\hline $50-59$ & 21 & 13.5 & 28 & 16.2 & 49 & 14.9 \\
\hline $60-69$ & 7 & 6.9 & 8 & 7.1 & 15 & 7.0 \\
\hline $70-79$ & 3 & 5.0 & 0 & 0.0 & 3 & 2.2 \\
\hline $80+$ & 2 & 6.0 & 0 & 0.0 & 2 & 2.2 \\
\hline Total $(95 \% \mathrm{Cl})$ & 90 & $9.7(7.7-11.7) \dagger$ & 80 & $8.0(6.2-9.8) \dagger$ & 170 & $8.8(7.5-10.1) \dagger \dagger$ \\
\hline
\end{tabular}

† Age-adjusted to the 2010 US White population. †† Age- and sex-adjusted to the 2010 US White population

Conclusion: In the Olmsted County population, the increasing PsA incidence seen in previous years $1970-1999^{1}$ seems to have leveled off after 2000 . This is in contrast to increasing incidence in recent years reported from Denmark, Taiwan and Israel. However, similar to our study, incidence rates for PsA from 2008-2015 were reported to be stable in Canada.

References:

[1] Wilson FC, Icen M, Crowson CS, McEvoy MT, Gabriel SE, Kremers HM. Time trends in epidemiology and characteristics of psoriatic arthritis over 3 decades: a population-based study. J Rheumatol. 2009;36(2):361-367.

Acknowledgments: This project was supported by CTSA Grant Number UL1 TR002377 from the National Center for Advancing Translational Science (NCATS).

Disclosure of Interests: Paras Karmacharya: None declared, Cynthia S. Crowson Grant/research support from: Pfizer research grant, Delamo Bekele: None declared, Sara Achenbach: None declared, John M Davis III Grant/research support from: Research grants from Pfizer, Consultant of: Served on advisory boards for Abbvie and Sanofi-Genzyme, Alexis Ogdie Grant/research support from: Pfizer, Novartis, Consultant of: Abbvie, Amgen, BMS, Celgene, Corrona, Janssen, Lilly, Pfizer, Novartis, Ali Duarte-Garcia: None declared, Hilal Maradit-Kremers: None declared, Megha Tollefson: None declared, Floranne C. Ernste: None declared, Kerry Wright: None declared

DOI: 10.1136/annrheumdis-2020-eular.2190

\begin{tabular}{|l|l}
\hline SAT0405 WITHDRAWN \\
\hline
\end{tabular}

